\title{
Factors affecting ground-water quality in Oakland County, Michigan
}

\section{What is ground water?}

Ground water is water stored in pores within soil and rock beneath the land surface. When these pores are connected so that water can be transmitted to wells or springs, these bodies of soil and rock are termed aquifers, from two Greek words meaning "water" and "to bear."

\section{Why is ground water important?}

Ground water is the primary source of drinking water for approximately 400,000 residents in Oakland County, Michigan. This drinking water is withdrawn from aquifers by private wells or larger community wells. Approximately 233,000 Oakland County residents use private wells for their household drinking water. More than 160,000 residents are served by over 140 public water suppliers, who provide drinking water for communities ranging from small subdivisions to large municipalities, such as Waterford Township. Over 95 percent of wells in the county draw water from the shallow glacial aquifer.

Ground water that is not withdrawn from the shallow glacial aquifer eventually flows into rivers, lakes, and wetlands in and around Oakland County. Ground water accounts for between 40 and 91 percent of all water in Oakland County rivers.

(Holtschlag and Nicholas, 1998). Nearly all of the water in rivers and wetlands during the dry summer months is from ground water. This water provides critical support for fish and other aquatic life. Unfortunately, contamination in ground water can spread into lakes and rivers.

Cleanup of contaminated ground water is an expensive and prolonged process, frequently taking decades. When groundwater supplies become contaminated, the community bears the cost through diminished property values, replacement or expansion of public water supplies, and replacement or abandonment of private domestic wells (Groundwater Education in Michigan, 1998; U.S. Environmental Protection Agency, 2004). The National Research Council (1994) has estimated that groundwater cleanup costs could reach $\$ 1$ trillion nationwide over the next 20 to 30 years.

\section{How does ground water become contaminated?}

Ground water can be considered contaminated whenever it is unsuitable for human use. However, there is a distinction between natural contamination and anthropogenic (humaninduced) contamination. Natural contamination is difficult, if not impossible, to control. In contrast, anthropogenic contami-

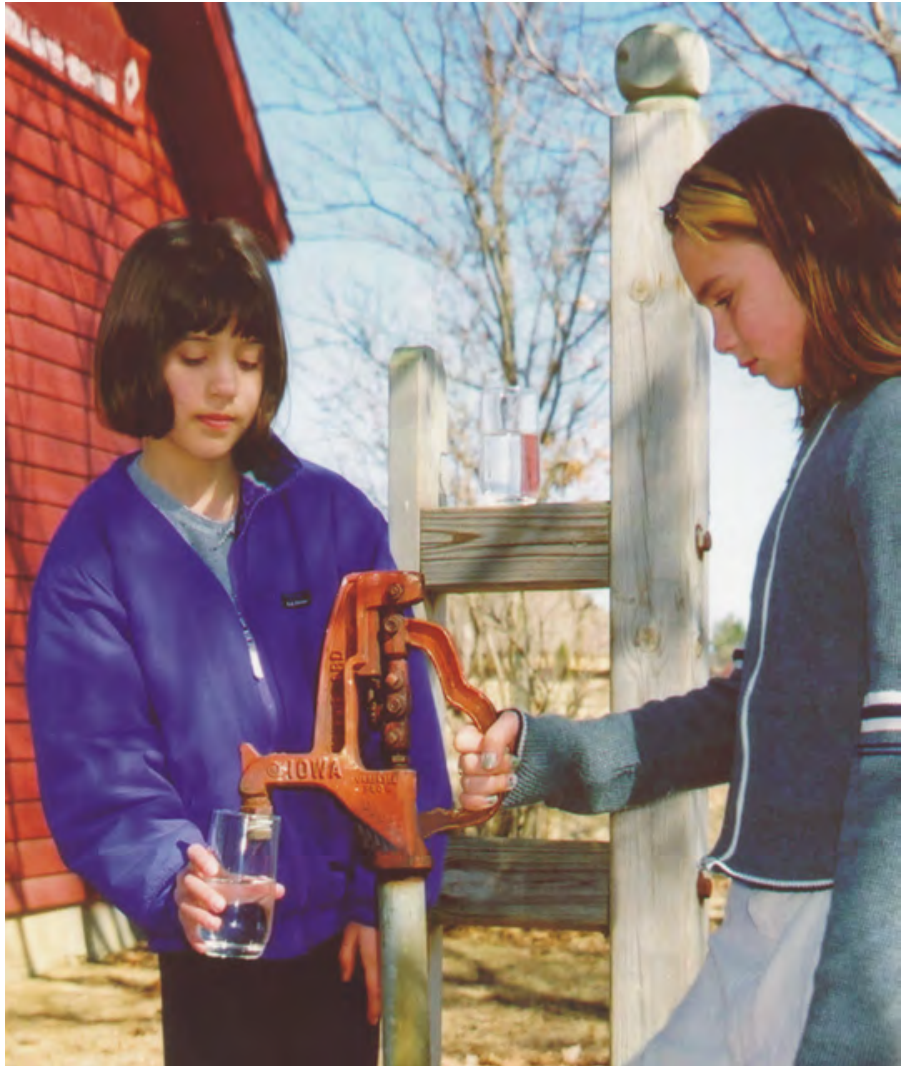

nation of ground water is usually the result of carelessness, ignorance, or negligence. Causes of contamination range from improper disposal of household waste to mishandled waste at industrial sites and from over-application of manure to leaking home heating oil tanks.

Ground water can become contaminated anywhere, but some areas are more susceptible than others because of the capacity of aquifer material (for example soil, sand, rock) to transmit water. Coarse materials like sand and gravel generally transmit water more rapidly than finer materials like clay and silt. Site-specific conditions such as soil properties, vegetation, and topography may affect contaminant transport. Nitrate and chloride, which are carried into ground water by rain percolating through the soils, are two widespread contaminants in Oakland County (Aichele, 2000). The predicted susceptibility of ground water in Oakland County to contamination by dissolved constituents like nitrate or chloride is shown in figure 1. This figure is based on estimated hydraulic conductivity maps developed by Bissell and Aichele (in press). 


\section{What are common sources of ground-water contamination?}

Nitrate is the most common ground-water contaminant in the United States, and it is common in ground water throughout Oakland County (Aichele, 2000). Although nitrate can occur naturally, elevated concentrations usually result from failing septic tanks or application of either manure or chemical fertilizers in excess of actual crop uptake. Contamination of ground water by failing septic tanks is a common cause of declining lake-water quality and algae growth in Michigan. Failing septic tanks and manure also can release bacteria and viruses into ground water.
Another common source of ground-water contamination is improperly maintained underground storage tanks (USTs). Underground storage tanks frequently are used to store gasoline, heating oil, and other fuels. When aging tanks begin to corrode, the contents can seep into ground water and cause a variety of undesirable chemical and biological effects.

In addition, improperly constructed or abandoned wells can contaminate ground water by allowing movement of contaminants from the surface directly down the side of the well casing into the aquifer. Properly grouting and sealing the hole around the well casing can eliminate a major route for contamination. Sealing unused wells removes a potential conduit for

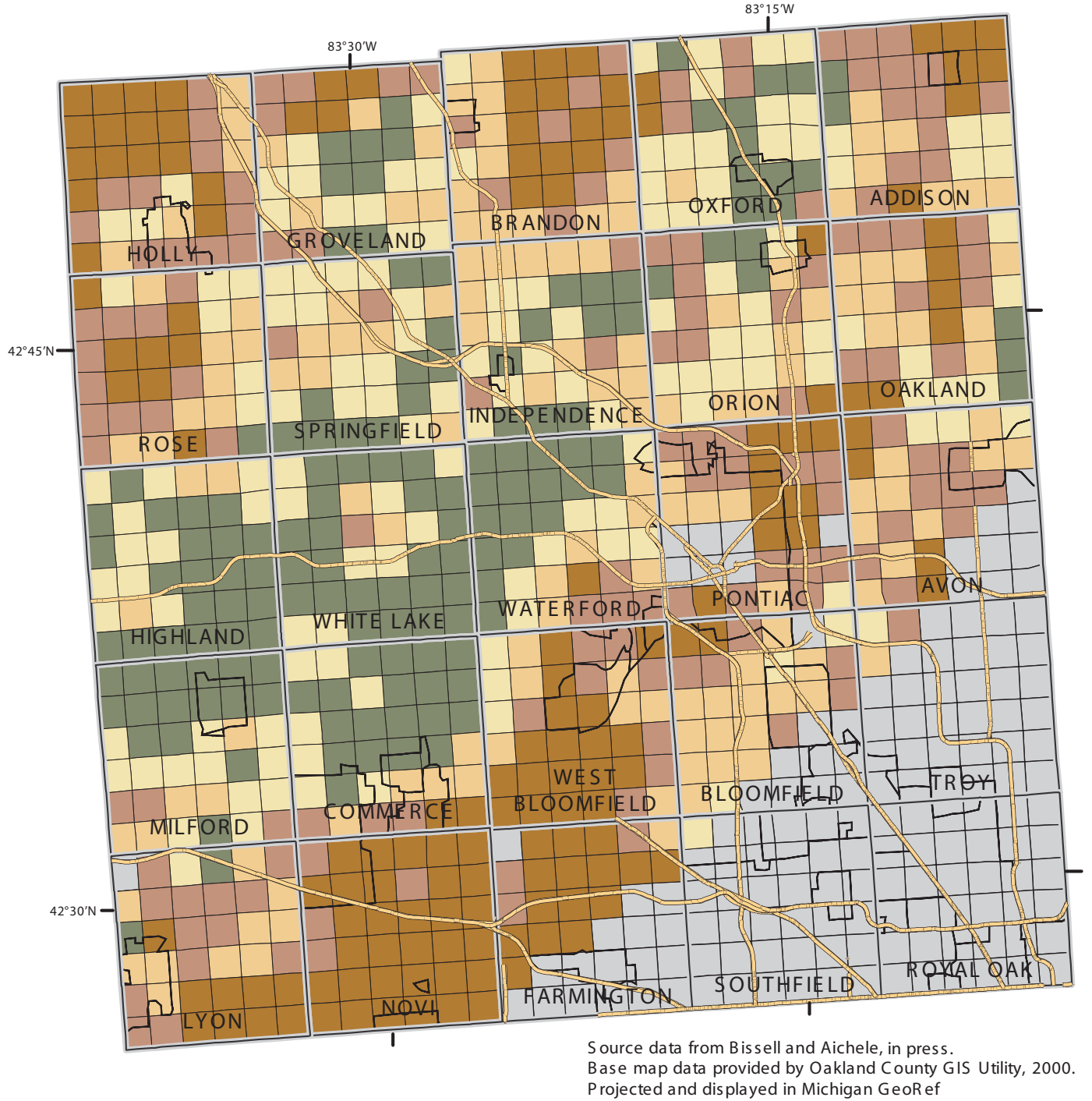

EXPLANATION
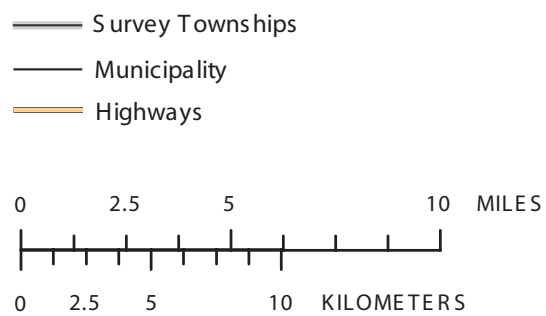

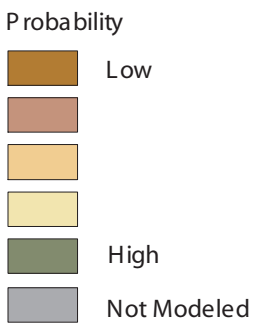

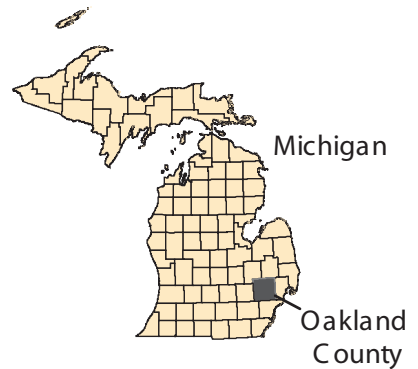

-Ground-water contamination can occur anywhere

-Anthropogenic contamination of ground water is usually the result of carelessness, ignorance, or negligence

-Some locations are more susceptible to contamination than others, becaue of the specific geologic setting

-Ground-water contamination can result in contamination of lakes and rivers

- Clean up of contaminated ground water is expensive and can take decades to complete

- Communities bear the cost of groundwater contamination, through diminished property values and increased infrastructure costs

Figure 1: Predicted suseptibility of ground water in Oakland County contamination by contaminants like nitrate and chloride. 
contaminants into the aquifer. Property owners can help by making sure no potential contaminants are released near their well.

\section{Do clay layers make any difference?}

A thick, continuous clay layer can be an effective barrier to movement of contaminants. However, clay layers also limit the rate at which precipitation can percolate through the soil to recharge aquifers. Geologic studies of Oakland County have shown that most of the clays in the county are discontinuous. The probability of encountering a clay layer more than 10 feet thick in different sections of Oakland County, based on the map published in Bissell and Aichele (in press) is shown in figure 2.
A comparison of figures 1 and 2 shows that although much of the county is likely to have a protective clay layer, the areas of the county most susceptible to contamination probably do not.

\section{How do I know if my ground water is contaminated?}

Public water supplies are regulated by Federal, State, and other agencies to ensure the water produced meets public health standards. Private domestic wells are not currently monitored by any governmental agency and are the responsibility of the owner.

Well owners interested in having their water tested can contact either the Oakland County Health Division or the

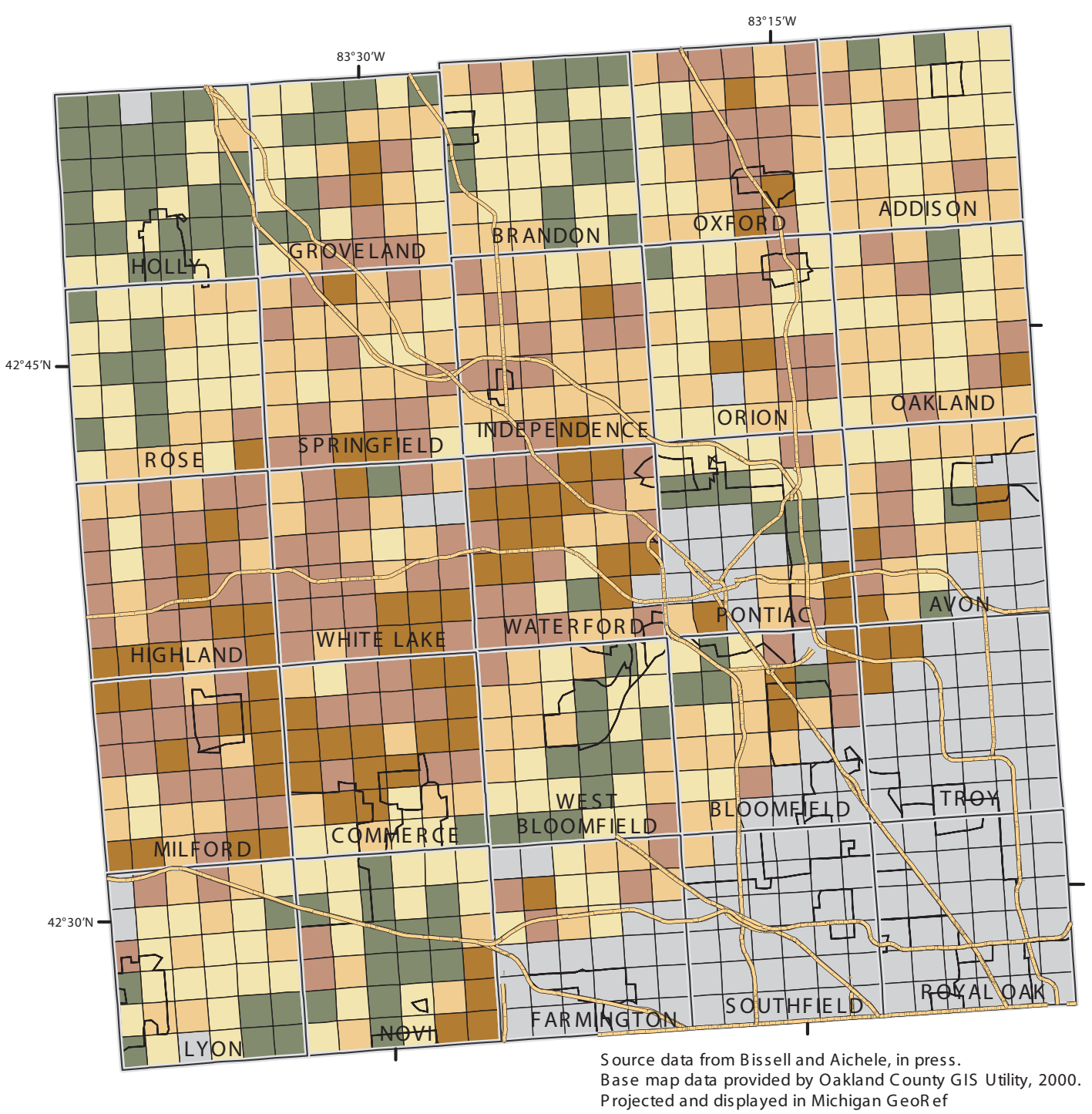

EXPLANATION
Probability

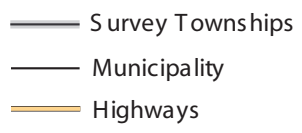

$\begin{array}{lll}0 & 2.5 \quad 5\end{array}$

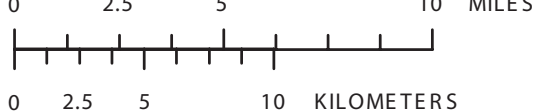

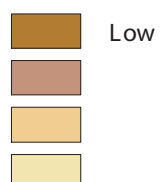

High

Not Modeled

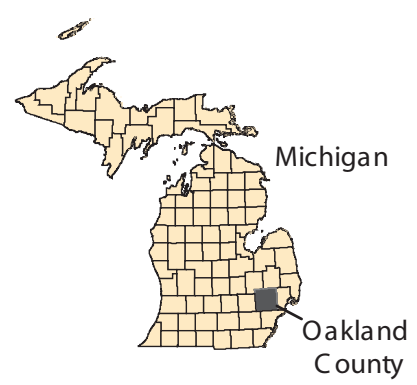

County

Figure 2: Predicted probability of encountering a clay layer ten or more feet thick in the glacial aquifer, 0akland County, Michigan.

- Clay layers can protect aquifers and ground water supplies from surface contamination

- Discontinuous clay layers may only provide limited protection

\section{-Well construction} practices, including proper grouting of the well casing, can help keep contaminants from traveling down the borehole beside the well casing

- Areas where clay layers do not exist are particularly vulverable to contamination from surface sources 
Michigan Department of Environmental Quality to obtain a list of laboratories that provide water-quality analyses (see box on this page).

\section{What can I do to prevent ground-water contamination?}

The most important thing to remember is that anything spilled in or on the ground has the potential to contaminate ground water. Even small amounts of fuels, lubricants, and waste can have serious effects on ground-water quality. Common household items, such as paints and paint thinner, cleaning agents, and batteries also pose a threat to ground-water quality. Handling these materials safely, and disposing of them properly, will help insure a continued supply of clean, fresh ground water for Oakland County residents and wildlife. For information about proper disposal of household chemicals, contact the Oakland County Health Division (see box on this page). For more detailed information on protecting and using ground water, the USGS booklet "Ground-water and the Rural Homeowner," available online at http://water.usgs.gov/pubs/gip/gw_ruralhomeowner.

\section{References Cited:}

Aichele, S.S., 2000, Ground-water quality atlas of Oakland County, Michigan: U.S. Geological Survey Water-Resources Investigations Report 00-4120, 53 p.

Bissell, E.G., and Aichele, S.S., in press, Geostatistical estimation of effective vertical hydraulic conductivity in the shallow glacial aquifer in Oakland County, Michigan: U.S. Geological Survey Scientific Investigations Report.

Groundwater Education in Michigan, 1998, Partnerships for Drinking Water Protection- Responsibilities and Opportunities. Groundwater Education in Michigan Fact Sheet 11, 4 p.

Holtschlag, D.J., and Nicholas, J.R., 1998, Indirect groundwater discharge to the Great Lakes. U.S. Geological Survey Open File Report 98-579, 8 p.

National Research Council, 1994, Alternatives for Groundwater cleanup: National Research Council, 336 p.

U.S. Environmental Protection Agency, 2004, Source water protection efforts. Accessed on April 26, 2004 at http://www. epa.gov/safewater/protect/protect.html on April 26, 2004.
For more information on ground water and ground-water protection, contact:

\author{
Oakland County Health Division \\ County Service Center \\ 1200 N. Telegraph Rd., Bldg. 36 \\ Pontiac, MI 48341 \\ http://www.co.oakland.mi.us/health
}

Michigan Department of Environmental

Quality, Water Division

P.O. Box 30473

Lansing, MI 48909

http://www.michigan.gov/deq

Michigan Department of Agriculture

Groundwater Stewardship Program

P.O. Box 30017

Lansing, MI 48909

http://www.michigan.gov/mda

U.S. Geological Survey

Water Resources Discipline

6520 Mercantile Way, Suite 5

Lansing, MI 48911

http://mi.water.usgs.gov

Groundwater Education in Michigan

(maintained by Michigan State Univer

sity Institute of Water Research)

http://www.gem.msu.edu

Ground-water and the Rural Homeowner available online at:

http://water.usgs.gov/pubs/gip/gw_ruralhomeowner 